\title{
Adaptation strategies of rare plant species to heterogeneous soil conditions on a coast of a lagoon lake as revealed by analysis of mycorrhizal symbiosis and mineral constituent dynamics
}

\author{
Andis Karlsons ${ }^{1}$, leva Druva-Lusite ${ }^{2}$, Jevgenija Necajeva², Una Andersone-Ozola², \\ Ineta Samsone ${ }^{2}$, Anita Osvalde', Gederts levinsh ${ }^{2 *}$ \\ ${ }^{1}$ Laboratory of Plant Mineral Nutrition, Institute of Biology, University of Latvia, Miera 3, Salaspils LV-2169, Latvia \\ ${ }^{2}$ Department of Plant Physiology, Faculty of Biology, University of Latvia, Jelgavas 1, Riga LV-1004, Latvia \\ *Corresponding author, E-mail: gederts@lanet.lv
}

\begin{abstract}
Soil chemical heterogeneity in sea-affected wetlands and its effect on mineral nutrition is a seldom studied aspect in ecophysiology of wild plants. The aim of the present study was to analyze seasonal changes in concentration of different mineral nutrients in leaves of several salt marsh species (Aster tripolium, Glaux maritima, Plantago maritima, Trifolium fragiferum, Triglochin maritima) in comparison to changes of plant-available nutrients in soil, with emphasis on mycorrhizal symbiosis. Extreme heterogeneity was noted for soil mineral nutrient concentrations, varying both spatially and temporiarily. A pronounced correlation between the concentrations of different soil mineral nutrients was observed. Early season flooding at the end of May coincided with a peak of summary precipitation and high sea level, and eventually resulted in significant increase in soil salinity in June. Peaks of $\mathrm{Na}$ and $\mathrm{Cl}$ accumulation in plant leaves in June were clearly related to the corresponding peak of soil concentrations of the respective ions. Seasonal trends of soil mineral concentrations were compared with respective leaf mineral concentration dynamics of the five species studied within the season. In general, a trend of leaf $\mathrm{N}$ concentration folowed that for soil $\mathrm{N}$ content. Minimum intensity and frequency of mycorrhizal symbiosis in July corresponded to the peak of soil salinity in June for roots of A. tripolium, G. maritima, P. maritima, and, possibly, T. fragiferum. Mycorrhizal symbiosis of G. maritima was the most sensitive to these conditions, with the intensity close to zero in July and August. Both intensity and frequency of mycorrhizal symbiosis in roots of T. maritima was highest in July, with significant decrease in August and September. The presence of arbuscules was evident in roots of all species, but with different intensity at different time points. The results of this study support the hypothesis that wild plants native to habitats with heterogeneous soil conditions have developed effective physiological adaptations allowing to grow normally and reproduce within a wide range of mineral concentration, as well as drastic changes in soil salinity.
\end{abstract}

Key words: chlorophyll $a$ fluorescence, mineral nutrients, mycorrhizal symbiosis, physiological adaptations, rare coastal plant species, soil chemical heterogeneity.

Abbreviations: EC, electrical conductivity; PI, Performance Index.

\section{Introduction}

Heterogeneous soil conditions affect plant localization and growth in salt marshes. In sea-affected marshes, fluctuations in water level lead to high heterogeneity in soil characteristics, including salinity and availability of mineral nutrients (Karlsons et al. 2011). In particular, shortage of nitrogen together with a high abundance of $\mathrm{P}$, $\mathrm{Mg}, \mathrm{Fe}, \mathrm{Zn}, \mathrm{Cu}$ on the background of significantly increased $\mathrm{NaCl}$ concentration are the most important characteristics of coastal wetlands. However, mineral nutrition of coastal marsh species is a less-studies aspect of coastal plant ecophysiology. In general, while the soil salinity-mineral nutrient relationship has been throughly studied with crop species (Grattan, Grieve 1999), the same problem has been less frequently investigated for wild plants in natural conditions.

It can be suggested that plant species composition of moderately saline temperate wetlands largely reflects a multitude of edaphic conditions. A number of relatively rare coastal marsh species are of special interest for ecophysiological studies. Several characteristic coastal marsh species (Plantago maritima, Triglochin maritima) represent typical leaf-succulent euhalophytes, characterized by almost cylindrical or globular leaves (Breckle 2002). Trifolium fragiferum, on the other hand, is a clonal species and typical legume, possesing rhyzobial symbiosis enabling to use nitrogen fixed from the air, and it is designated as facultative halophyte (Rumbaugh et al. 1993; Nienartowicz, Wilkon-Michalska 1993). Aster tripolium is a salt-recreting 
halophyte, having rapid turnover of leaves, replacing older leaves that have a high concentration of salt (Breckle 2002). Glaux maritima is a species capable for vegetative propagation characterized by the presence of salt glands with a relatively high efficiency of salt removal (Rozema et al. 1978).

Usually it is assumed that mycorrhizal symbiosis is an important adaptation of wild plants to nutrientlimited conditions (Ruiz-Lozano, Azcón 2000) and it can also contribute to stress tolerance (Feng et al. 2002). In a complex study of putative mycorrhizal structures in roots of 29 coastal plant species it was revealed that coastal salt marsh species Aster tripolium, Glaux maritima, Plantago maritima, Trifolium fragiferum, Triglochin maritima display mycorrhiza-specific structures in their roots, including hyphae, vesicles and arbuscules (Druva-Lusite, Ievinsh 2010), pointing to existence of functionally active symbiosis in these plants. However, the intensity of symbiosis was variable and at relatively low level, reaching above $10 \%$ only for Aster tripolium, Plantago maritima and Trifolium fragiferum. It was argued that increased soil salinity is among the main environmental factors resulting in decreased intensity of mycorrhizal symbiosis of salt marsh species (Druva-Lusite, Ievinsh 2010).

It is not completely understood how different plant species adapt to highly heterogeneous soil conditions of saline wetland. The most important problem concerns physiological mechanisms in saline wetland plants with possible adaptive importance, including mycorrhizal symbiosis and adaptivity of mineral nutrition. It can be suggested that specific physiological adaptation mechanisms exist to maintain mineral equilibrium in plant tissues at optimal levels through acquisition, transport and efficiency of use of mineral nutrients. The aim of the present study was to analyze seasonal changes in concentration of different mineral nutrients in leaves of number of salt marsh species in comparison to changes of plant-available nutrients in soil, with emphasis on mycorrhizal symbiosis.

\section{Materials and methods}

Wet meadows on the coast of Lake Liepaja are periodically flooded by water from the lake during heavy and prolonged rains through changes in water level and are affected by the Baltic Sea. Lake Liepaja is a typical lagoon-type lake, in the northern part connected with the Baltic Sea by a channel which results in relatively high water salinity at the northern ( 8 to $10 \mathrm{dS} \mathrm{m}^{-1}$ ) and central part ( 2 to 4 $\mathrm{dS} \mathrm{m}^{-1}$ ) due to the action of prevailing northwest winds (Latvian Environmental Protection Fund 2008). This forms characteristic coastal salt marsh vegetation on the coasts of the Lake with several rare or especially protected species [Aster tripolium L., Blysmus rufus (Huds.) Link, Glaux maritima L., Juncus gerardii Loisel., Plantago maritima L., Spergularia salina J. et C. Presl, Triglochin maritima L. etc.]. However, characteristic halophyte vegetation has established only in places with significant anthropogenic pressure, around paths and near the coast, or in the form of small islands surrounded by relatively high herbaceous vegetation composed mostly of Phragmites communis L., Typha spp. and various characteristic dicotyledonous wet meadow species.

The particular study site along Eduarda Tisē Street in Liepaja was localized in the part of the lake with water salinity about $7 \mathrm{dS} \mathrm{m}^{-1}$ (Latvian Environmental Protection Fund 2008). The water in this area has a high concentration of dissolved $\mathrm{P}\left(>0.08 \mathrm{mg} \mathrm{L}^{-1}\right)$. As model species for this study, the especially protected coastal marsh species Aster tripolium, Glaux maritima, Plantago maritima, Trifolium fragiferum, and Triglochin maritima were chosen (Cabinet of Ministers of Latvia 2000). Three subsites identically affected by water level changes were selected within a different distance from the coast ( 3 to $15 \mathrm{~m}, 120 \mathrm{~m}, 170$ $\mathrm{m})$ in places where the model plant species were located. Small-scale spatial heterogeneity in soil properties were eliminated by sampling in different locations within the particular subsite and by using plant material from various locations for mineral constituent analysis. Every month three to five samples were taken from each subsite and analyzed separately for concentration of plant-available mineral nutrients, $\mathrm{pH}$ and EC as described previously (Karlsons et al. 2008). Average monthly values from each subsite were used to calculate average values for the site.

Plant material for chemical analysis was collected monthly from May till September within the period between the dates $10^{\text {th }}$ and $15^{\text {th }}$. To ensure non-disturbing plant sampling, three leaf samples were collected for each

Table 1. Variation of soil mineral nutrient, $\mathrm{Na}$ and $\mathrm{Cl}$ concentration $\left(\mathrm{mg} \mathrm{L}^{-1}\right), \mathrm{pH}$ and EC during the vegetation season. $n=38$

\begin{tabular}{lccc|} 
& $\begin{array}{c}\text { Mean value } \\
\pm \mathrm{SE}\end{array}$ & Range & $\begin{array}{c}\text { Coefficient } \\
\text { of } \\
\text { variation } \\
\text { (\%) }\end{array}$ \\
Nitrogen (N) & $45 \pm 4$ & $14 \div 108$ & 55 \\
Phosphorus (P) & $224 \pm 27$ & $92 \div 916$ & 74 \\
Potassium (K) & $98 \pm 11$ & $17 \div 270$ & 71 \\
\hline Calcium (Ca) & $8564 \pm 800$ & $1313 \div 22938$ & 58 \\
Magnesium (Mg) & $1799 \pm 06$ & $650 \div 2875$ & 33 \\
\hline Sulphur (S) & $510 \pm 99$ & $40 \div 2400$ & 121 \\
Iron (Fe) & $1740 \pm 252$ & $300 \div 8350$ & 90 \\
\hline Manganese (Mn) & $94 \pm 16$ & $8 \div 400$ & 105 \\
Zinc (Zn) & $29 \pm 4$ & $4 \div 90$ & 77 \\
\hline Copper (Cu) & $3.0 \pm 0.3$ & $0.5 \div 7.5$ & 63 \\
Molybdenum (Mo) & $0.039 \pm 0.003$ & $0.01 \div 0.09$ & 46 \\
\hline Boron (B) & $4.6 \pm 0.6$ & $0.2 \div 13.2$ & 76 \\
\hline Sodium (Na) & $1200 \pm 184$ & $225 \div 5150$ & 96 \\
\hline Chlorine (Cl) & $1357 \pm 202$ & $275 \div 6300$ & 92 \\
\hline pH & $7.0 \pm 0.2$ & $4.2 \div 8.5$ & 14 \\
\hline EC & $6.4 \pm 0.9$ & $1.3 \div 25.5$ & 81 \\
\hline
\end{tabular}


plant species, each consisting of one fully grown leaf from a number (at least, 10) of individual plants. Concentration of $\mathrm{Na}, \mathrm{Cl}$ and mineral nutrients in leaf tissues was analyzed as described previously (Karlsons et al. 2008). Root samples for analysis of mycorrhizal symbiosis were obtained from a rhizosphere of intact plants (Andersone et al. 2011), prepared and measured as described previously (DruvaLūsīte et al. 2008).

Chlorophyll $a$ fluorescence was measured monthly using a Handy PEA comtinuous florescence meter (Hansatech Instruments, UK) as described previously (Druva-Lūsìte et al. 2008). For each time point, at least 10 plants per species were analyzed with five individual measurements each.

Climate data (summary precipitation and sea level changes) were obtained from the Latvian Environment, Geology and Meteorology Centre (http://www.meteo.lv) and recalculated according to the time of analysis separately for the first and the second half of the month.

\section{Results}

Extreme heterogeneity was noted for soil mineral nutrient concentrations, varying both spatially and temporarly (Table 1). The lowest variability in soil samples during the season (as indicated by the respective coefficients of variation) was found for $\mathrm{Mg}$ (33\%), followed by Mo (46\%). Moderate variability (55 to 63\%) was characteristic for $\mathrm{N}, \mathrm{Ca}, \mathrm{Cu}$ and increased (71 to $76 \%$ ) variability for $\mathrm{K}, \mathrm{P}$, $\mathrm{B}, \mathrm{Zn}$. High variability (90 to $105 \%$ ) was found for $\mathrm{Fe}, \mathrm{Cl}$, $\mathrm{Na}, \mathrm{Mn}$, and the highest was for S (121\%). Soil salinity was also highly variable (81\%), to a large extent reflecting high variation in $\mathrm{Na}(96 \%)$ and $\mathrm{Cl}(92 \%)$ concentration.

Early season flooding at the end of May coincided with a peak of cumulative precipitation and high sea level, and eventually resulted in significant increase in soil salinity in June (Fig. 1). Peaks of $\mathrm{Na}$ and $\mathrm{Cl}$ accumulation in plant leaves in June (Fig. 2B, 3B) were clearly related to the corresponding peak of soil concentrations of respective ions (Fig. 2A, 3A). Interestingly, all species accumulated comparable concentrations of $\mathrm{Na}$ in June, while at the end of the vegetation season, in conditions of lowered soil Na concentration, T. maritima and P. maritima had significantly higher leaf tissues levels of $\mathrm{Na}$ in comparison to A. tripolium, G. maritima and T. fragiferum (Fig. 2B). The same phenomenon was evident for $\mathrm{Cl}$ ions (Fig. 3B). In addition, G. maritima plants accumulated relatively less $\mathrm{Cl}$ ions in June in comparison to $\mathrm{Na}$ ions.

Seasonal trends of respective soil mineral concentrations were compared with leaf mineral concentration dynamics of the five species studied within a season. In general, a trend of leaf $\mathrm{N}$ concentration folowed that for soil $\mathrm{N}$ content (Fig. 4). Both T. fragiferum and T. maritima accumulated higher concentration of $\mathrm{N}$, which was especially pronounced at the end of the vegetation season, with more than three-fold $\mathrm{N}$ concentration in comparison to the rest of the species. Another notable characteristic was high $\mathrm{N}$ concentration in developing leaves in May for all species analyzed except A. tripolium.

Plant-available concentration of soil $\mathrm{P}$ was high in May and June, significantly lower in July and August, with some increase again in September (Fig. 5A). A trend in tissue concentration of $\mathrm{P}$ was similar to that in soil for all species except T. maritima, but there was no increase in $\mathrm{P}$ concentration in September (Fig. 5B). Plant-available concentration of soil $\mathrm{K}$ was high in May and September with significantly lower level in June, July and August (Fig. $6 \mathrm{~A})$. Concentration of $\mathrm{K}$ in leaf tissues was at the highest level in May followed by a significant decrease in July (Fig. 6B).

In spite of the relatively stable soil $\mathrm{Ca}$ (Fig. 7A) and $\mathrm{Mg}$ (Fig. 8A) concentration during the season, some species (P. maritima and A. tripolium for $\mathrm{Ca}$, and P. maritima for $\mathrm{Mg}$ ) exhibited significantly higher concentration of $\mathrm{Ca}$ and $\mathrm{Mg}$ ions in May and June (Fig. 7B and 8B). Changes in soil concentration of plant available $S$ were similar to those of $\mathrm{P}$ (Fig. 9A), but this was not reflected by $\mathrm{S}$ concentration in plant tissues (Fig. 9B). Similarly, significantly higher concentration of plant-available $\mathrm{Fe}$ in soil (Fig. 10A)
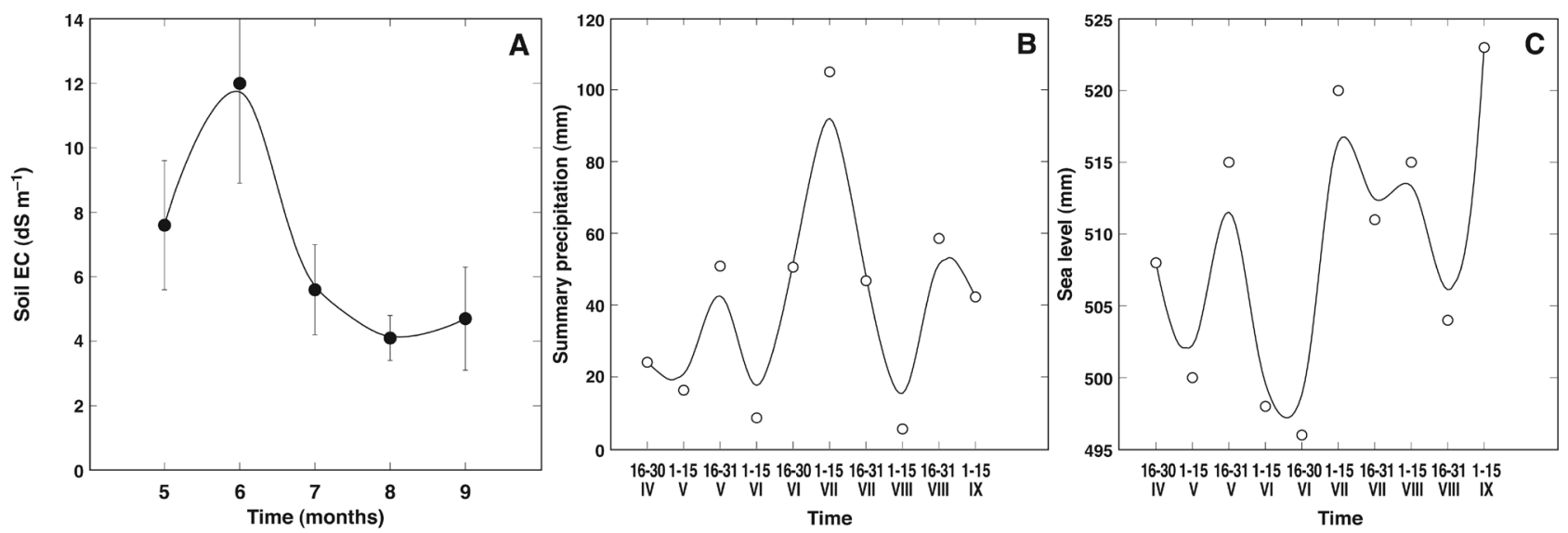

Fig. 1. Changes of soil electrical conductivity (EC; A), cumulative precipitation (B) and sea level (C) in Liepaja within the vegetation season. 

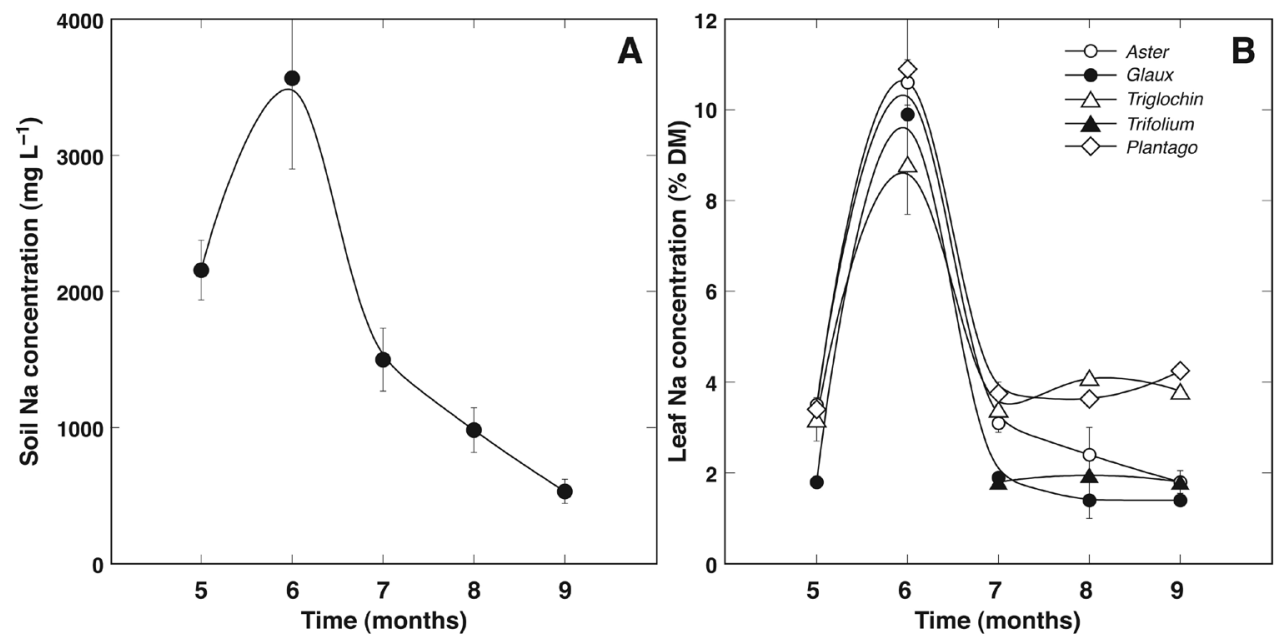

Fig. 2. Changes of Na concentration in soil (A) and plant leaves (B) during the vegetation season. Data are means \pm SE from 12 samples for soil concentration and from three samples for each plant species for each time point.
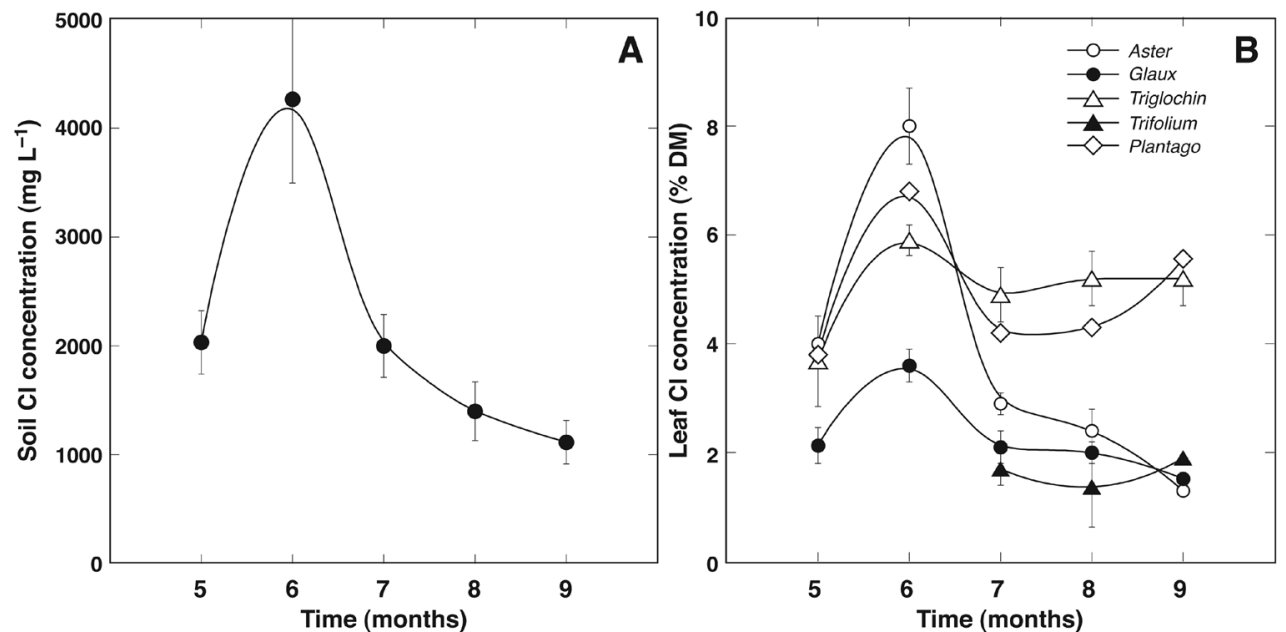

Fig. 3. Changes of $\mathrm{Cl}$ concentration in soil (A) and plant leaves (B) during the vegetation season. Data are means $\pm \mathrm{SE}$ from 12 samples for soil concentration and from three samples for each plant species for each time point.
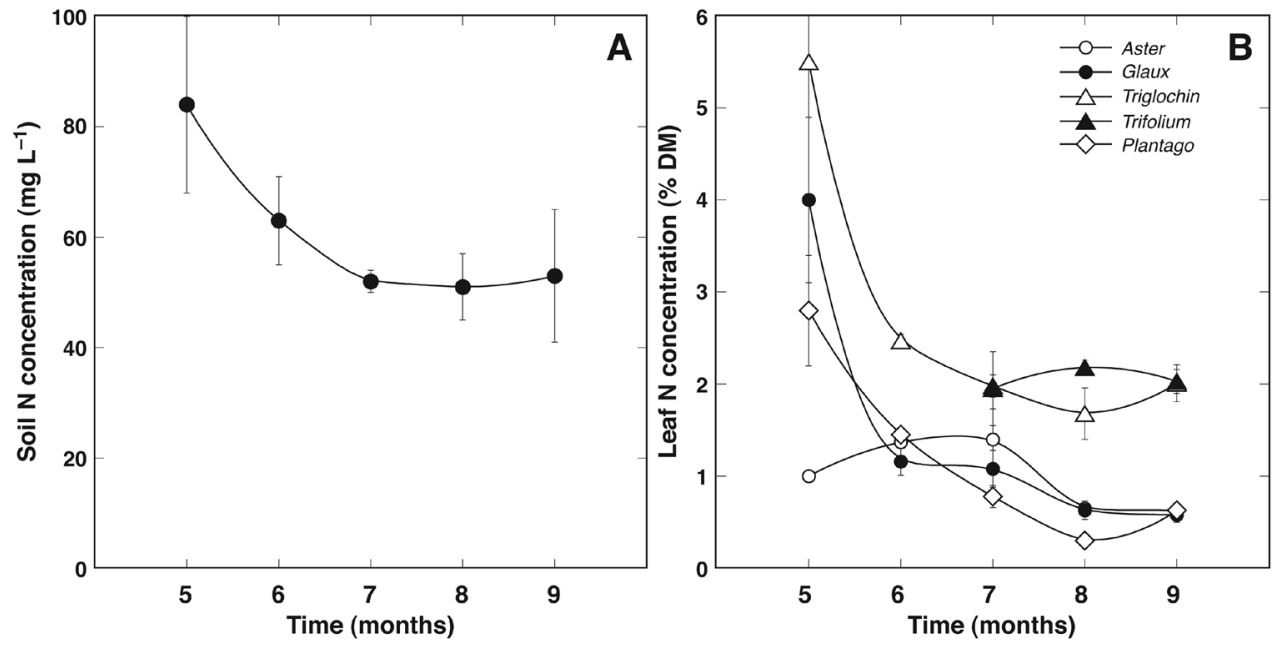

Fig. 4. Changes of $\mathrm{N}$ concentration in soil (A) and plant leaves (B) during the vegetation season. Data are means \pm SE from 12 samples for soil concentration and from three samples for each plant species for each time point. 

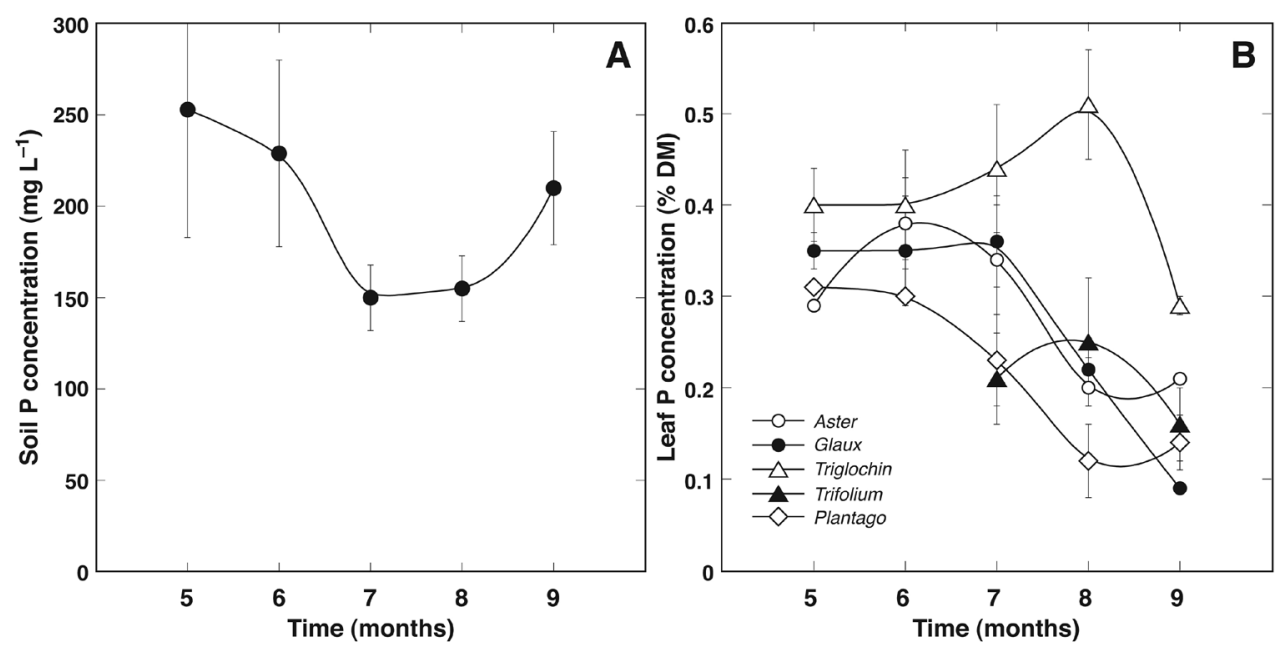

Fig. 5. Changes of $P$ concentration in soil (A) and plant leaves (B) during the vegetation season. Data are means \pm SE from 12 samples for soil concentration and from three samples for each plant species for each time point.
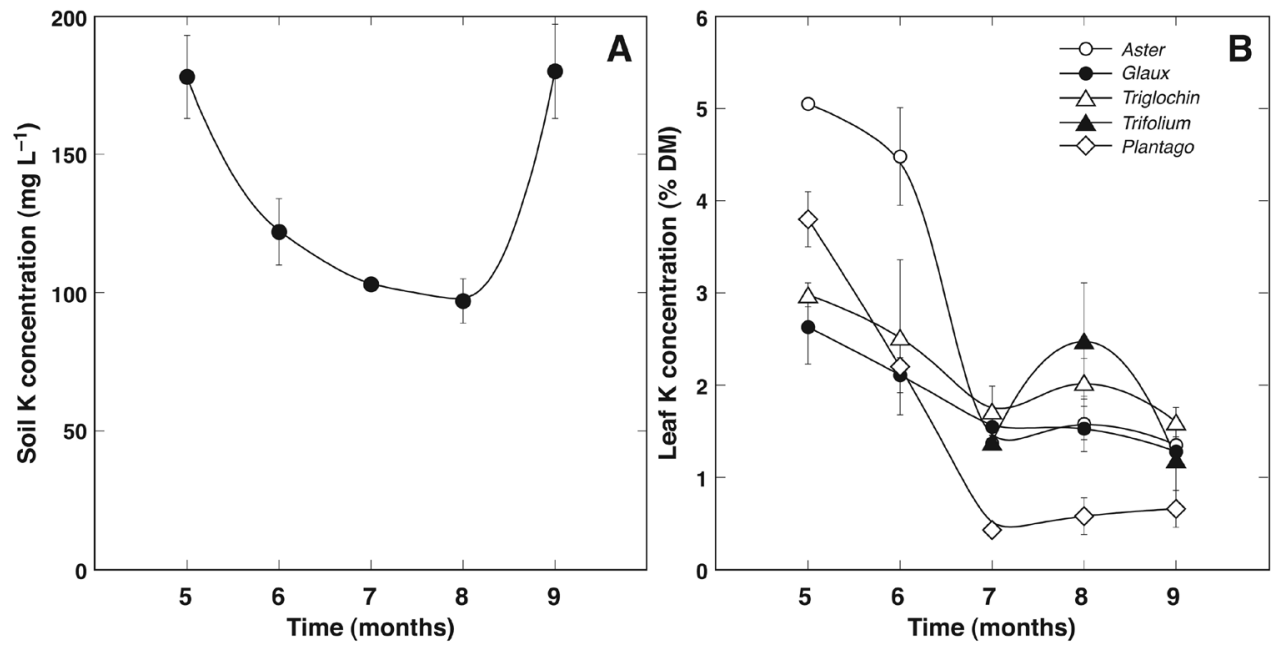

Fig. 6. Changes of $K$ concentration in soil (A) and plant leaves (B) during the vegetation season. Data are means \pm SE from 12 samples for soil concentration and from three samples for each plant species for each time point.
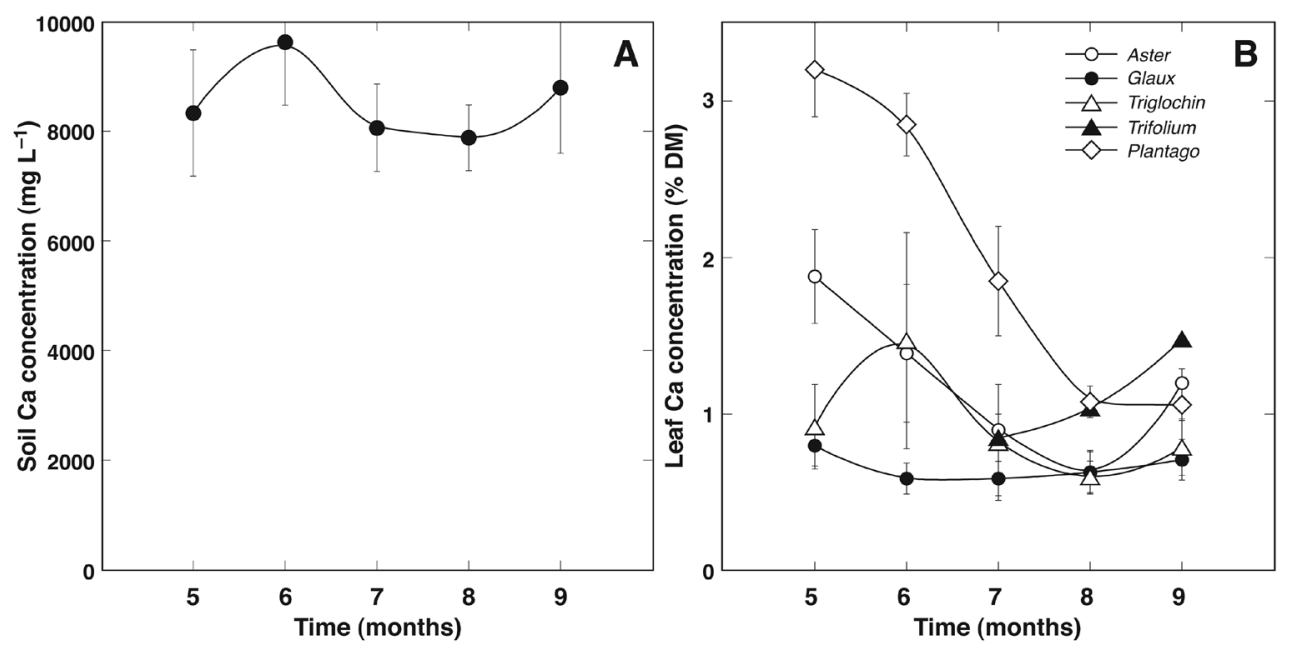

Fig. 7. Changes of Ca concentration in soil (A) and plant leaves (B) during the vegetation season. Data are means \pm SE from 12 samples for soil concentration and from three samples for each plant species for each time point. 

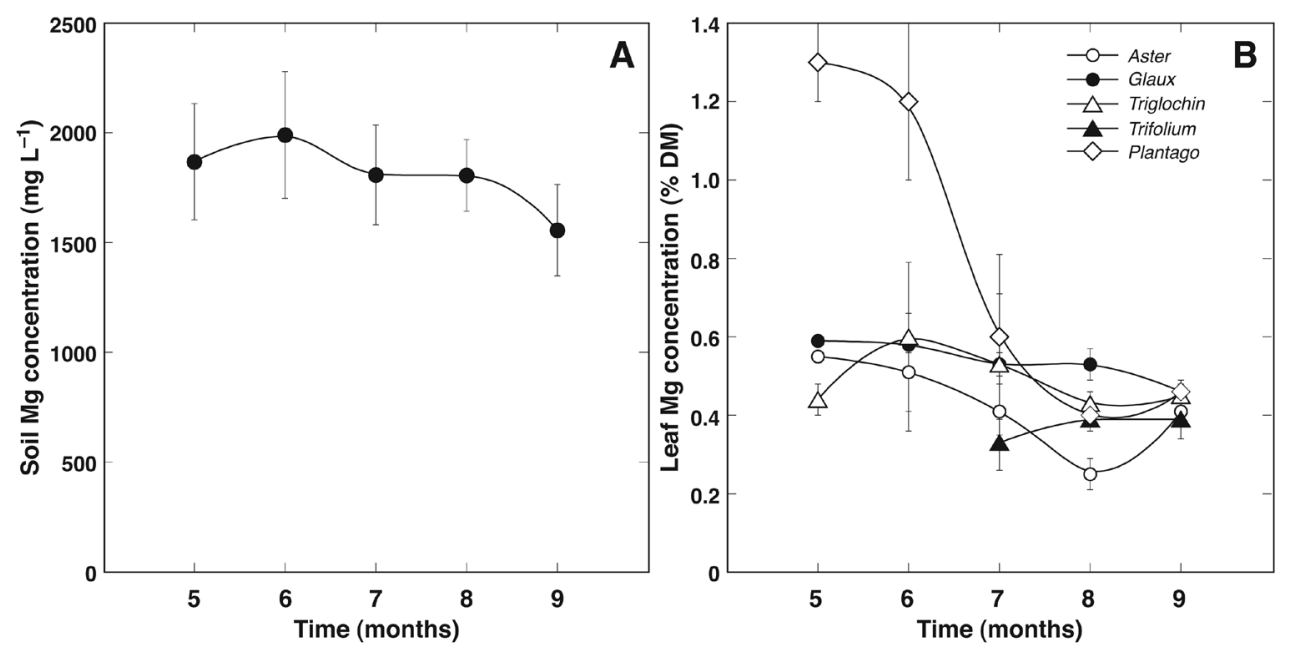

Fig. 8. Changes of Mg concentration in soil (A) and plant leaves (B) during the vegetation season. Data are means \pm SE from 12 samples for soil concentration and from three samples for each plant species for each time point.
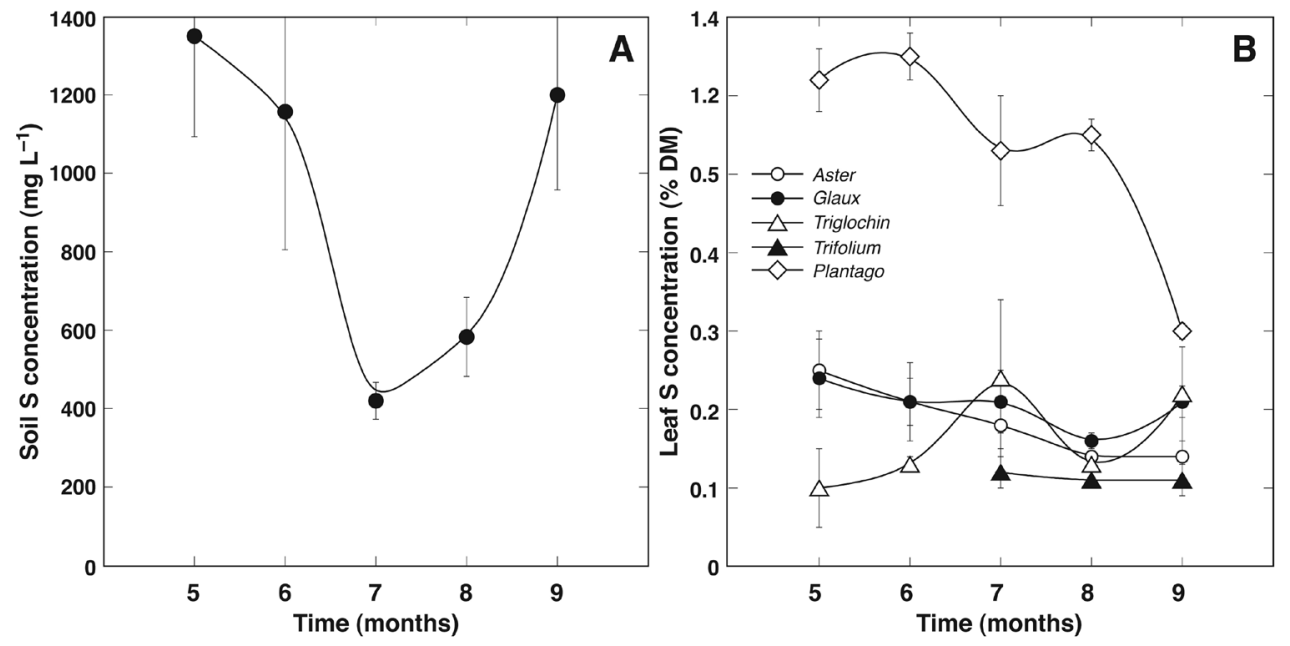

Fig. 9. Changes of S concentration in soil (A) and plant leaves (B) during the vegetation season. Data are means \pm SE from 12 samples for soil concentration and from three samples for each plant species for each time point.
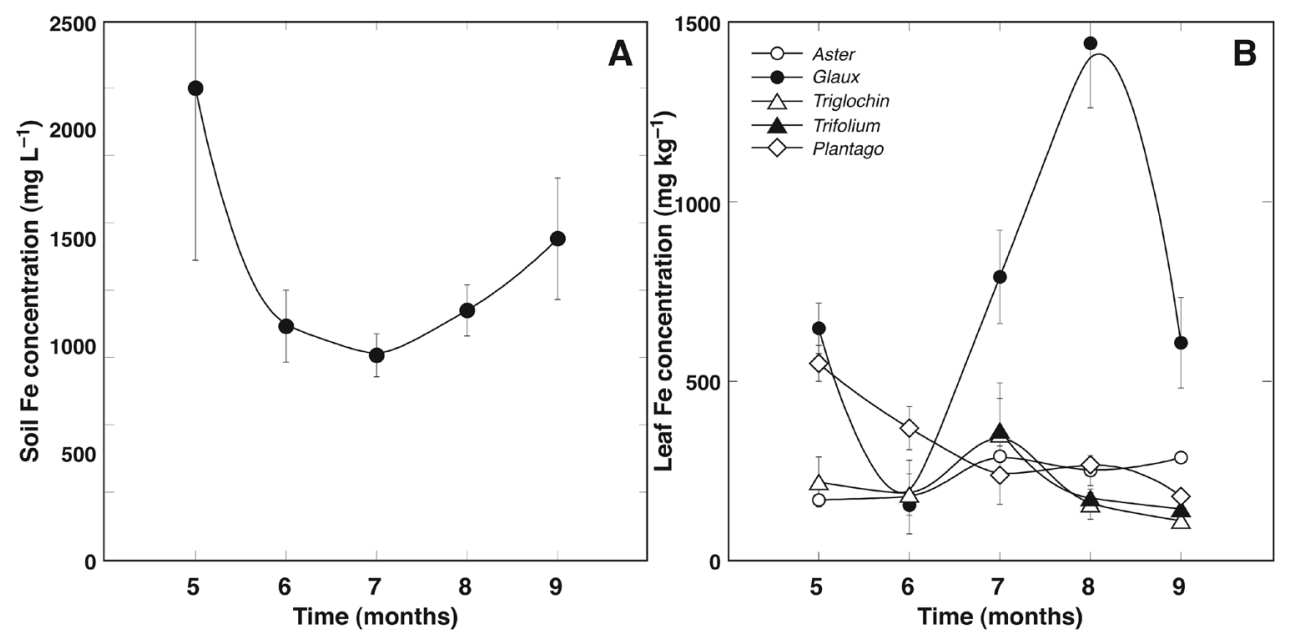

Fig. 10. Changes of Fe concentration in soil (A) and plant leaves (B) during the vegetation season. Data are means \pm SE from 12 samples for soil concentration and from three samples for each plant species for each time point. 

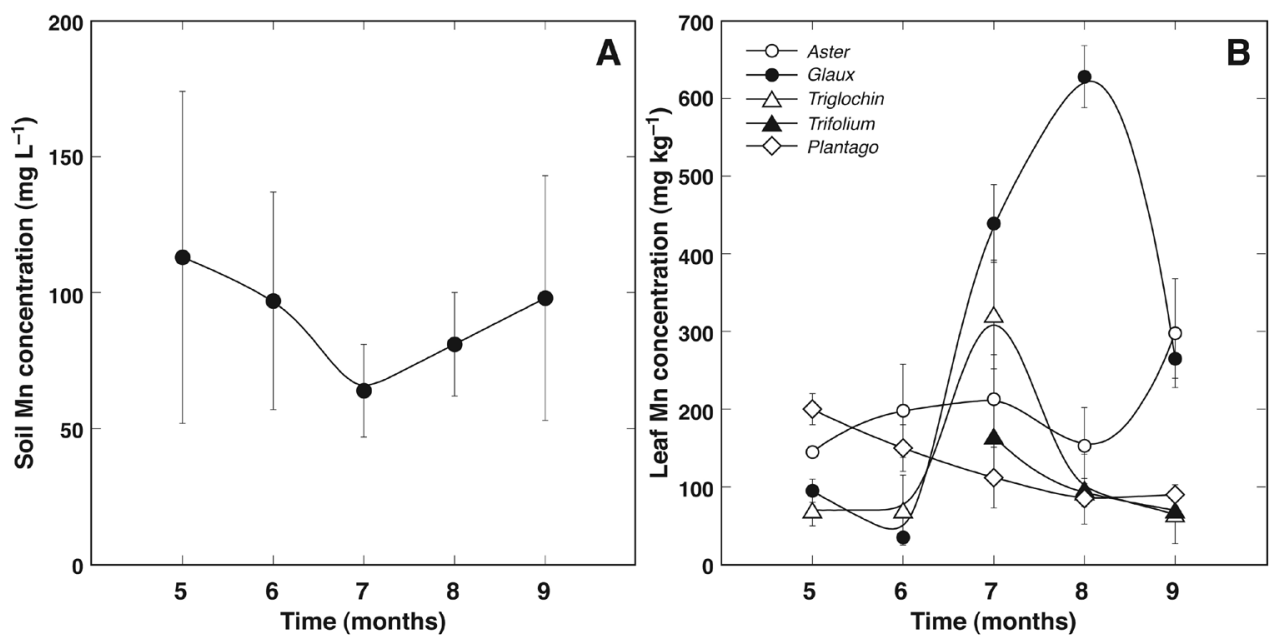

Fig. 11. Changes of Mn concentration in soil (A) and plant leaves (B) during the vegetation season. Data are means \pm SE from 12 samples for soil concentration and from three samples for each plant species for each time point.
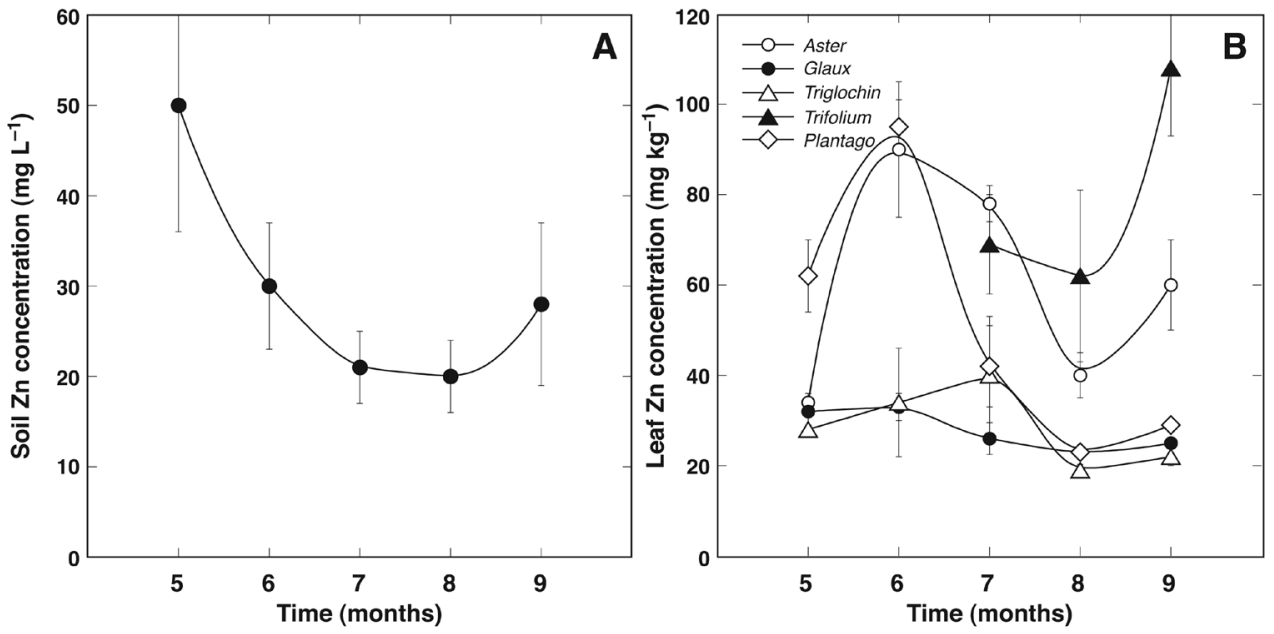

Fig. 12. Changes of $\mathrm{Zn}$ concentration in soil (A) and plant leaves (B) during the vegetation season. Data are means \pm SE from 12 samples for soil concentration and from three samples for each plant species for each time point.
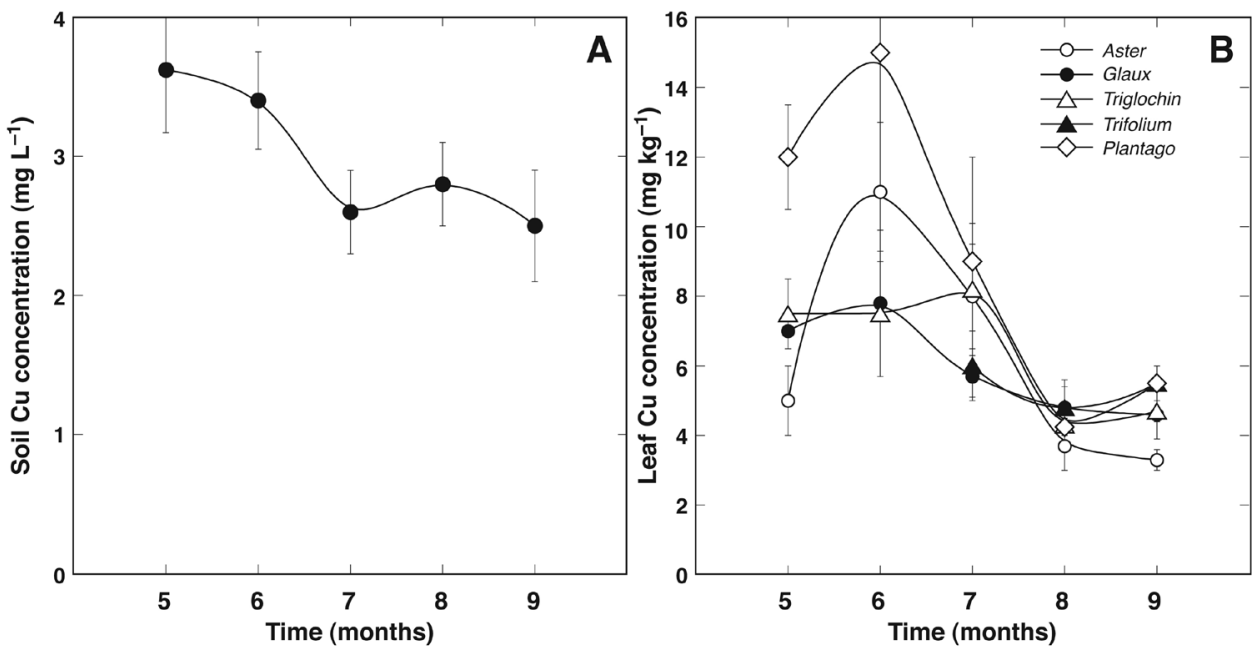

Fig. 13. Changes of $\mathrm{Cu}$ concentration in soil (A) and plant leaves (B) during the vegetation season. Data are means \pm SE from 12 samples for soil concentration and from three samples for each plant species for each time point. 

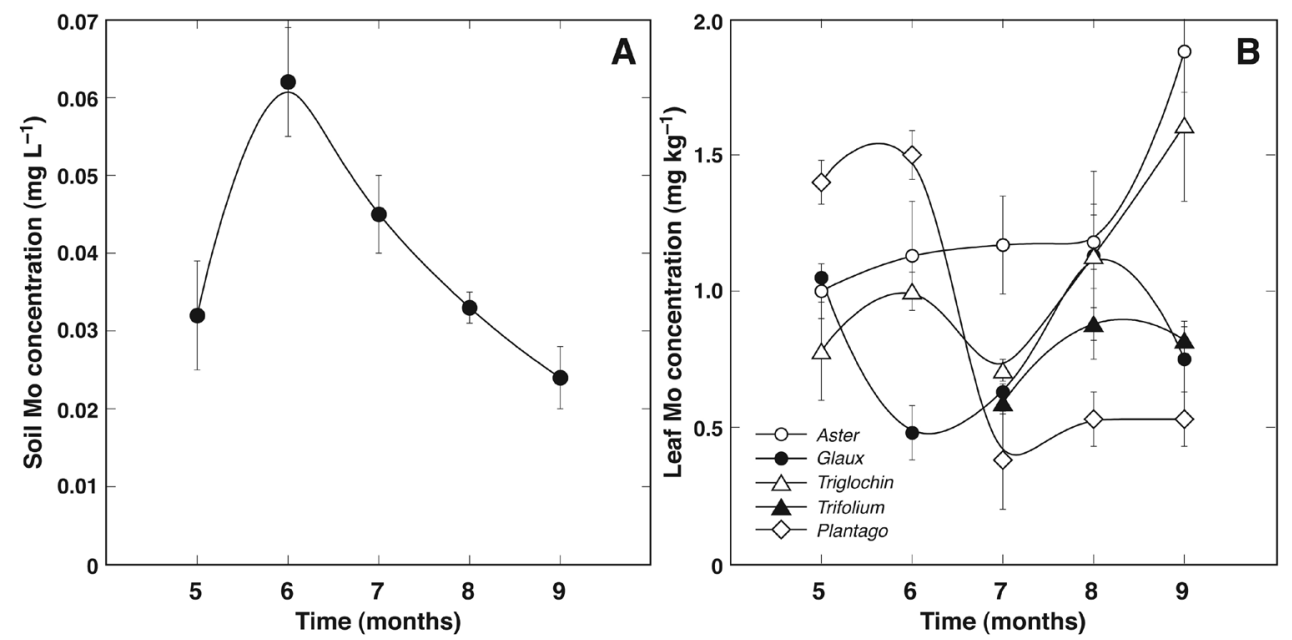

Fig. 14. Changes of Mo concentration in soil (A) and plant leaves (B) during the vegetation season. Data are means \pm SE from 12 samples for soil concentration and from three samples for each plant species for each time point.
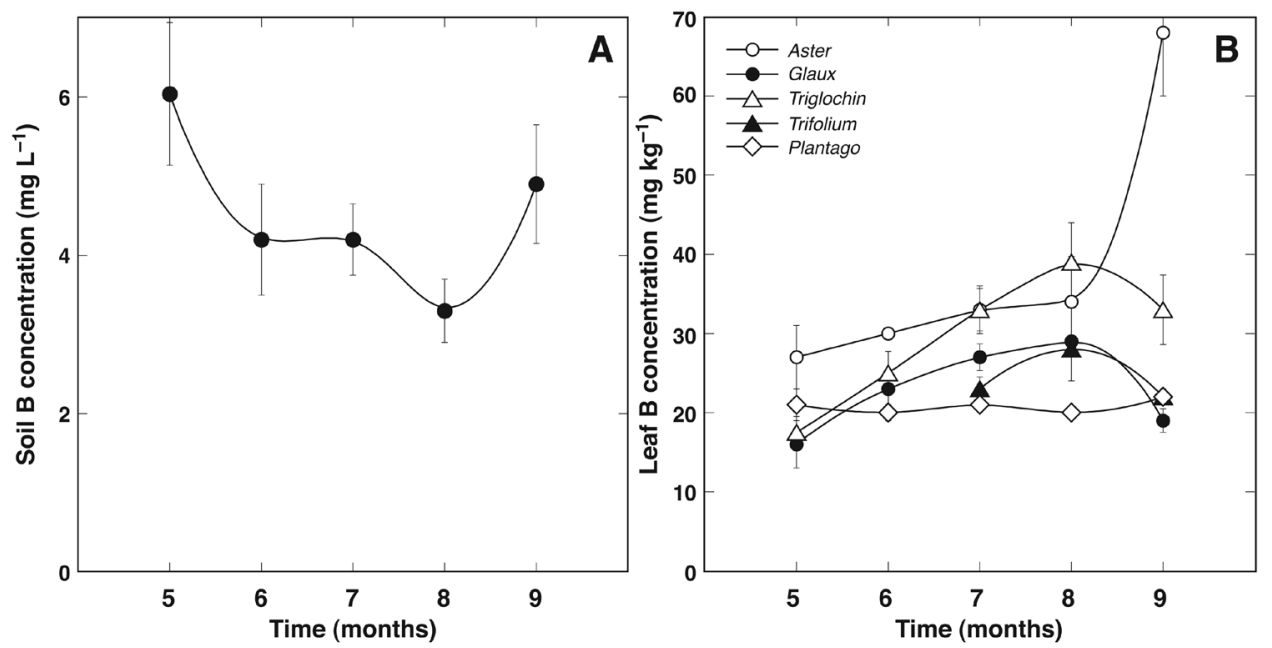

Fig. 15. Changes of B concentration in soil (A) and plant leaves (B) during the vegetation season. Data are means \pm SE from 12 samples for soil concentration and from three samples for each plant species for each time point.

was not reflected by corresponding changes in leaf $\mathrm{Fe}$ concentration (Fig. 10B).

Plant-available concentration of soil $\mathrm{Mn}$ (Fig. 11A), Zn (Fig. 12A) and $\mathrm{Cu}$ (Fig. 13A) did not change significantly during the season, but their seasonal pattern of accumulation in plant leaves was clearly species-specific (Fig. 11B, 12B, 13B). A highly variable accumulation trend in leaves was evident also for Mo (Fig. 14B), which showed the same pattern in soil as that of $\mathrm{Na}$ and soil EC (Fig. 14A). Soil B concentration was high in May and September (Fig. $15 \mathrm{~A}$ ) but tissue concentration of $\mathrm{B}$ was stable or slowly rising (Fig. 15B).

In July and August G. maritima plants showed relatively high increase of Fe (7-fold) and Mn (6-fold) concentration in comparison to average values of other plants. In May and June P. maritima plants exhibited significantly higher tissue concentration of $\mathrm{Ca}, \mathrm{Mg}$ and $\mathrm{S}$ in comparison with other plants, coinciding with the highest level of soil salinity
(Fig. 7, 8, 9). For S, increased level in P. maritima leaves was maintained also in July and August, diminishing only in September (Fig. 9).

Minimum intensity and frequency of mycorrhizal symbiosis in July corresponded to the peak of soil salinity in June for roots of A. tripolium, G. maritima, P. maritima, and, possibly, T. fragiferum (Fig. 16). Mycorrhizal symbiosis of $G$. maritima was the most sensitive to these conditions, with mycorrhiza intensity close to zero in July and August (Fig. 16B). Arbusclues in roots of G. maritima were evident only in September with relatively high intensity ( $51.1 \%$, data not shown). In contrast, both intensity and frequency of mycorrhizal symbiosis in roots of T. maritima was highest in July, with significant decrease in August and September (Fig. 16C). The presence of arbuscules was evident in roots of T. maritima plants from July till September, with increasing intensity $(14.3,20.6,23.6 \%$, in July, August, September, respectively; Fig. 16E). For P. maritima, intensity 

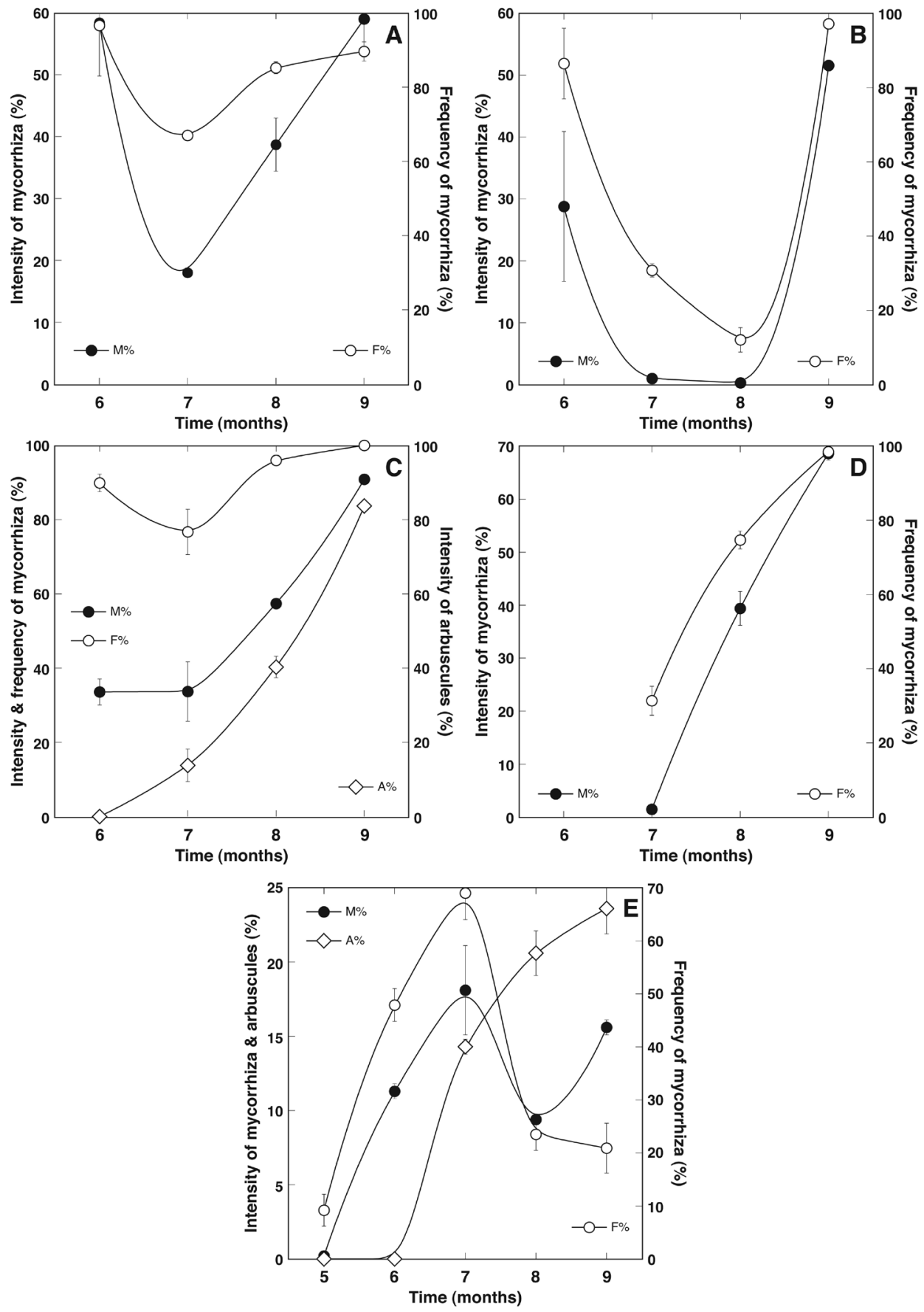

Fig. 16. Seasonal dynamics of intensity of mycorrhizal symbiosis (M\%), frequency of mycorrhizal symbiosis (F\%) and intensity of arbuscules of mycorrhizal symbiosis (A\%) in roots of Aster tripolium (A), Glaux maritima (B), Plantago maritima (C), Trifolium fragiferum (D), Triglochin maritima (E). Data are means \pm SE from 3 measurements for each time point. M\%, intensity of mycorrhiza; $\mathrm{A} \%$, intensity of arbuscules; F\%, frequency of mycorrhiza.

and frequency of mycorrhizal symbiosis had different character. While intensity was relative low in June and July and increased in August and September, frequency was high during the season (Fig. 16C). Arbuscules in roots of P. maritima plants ocurred with increasing intensity during the season (Fig. 16C). In roots of A. tripolium there was a significant decrease in both myorrhizal intensity and frequency in July followed by a recovery later in the season (Fig. 16A). In contrast, arbuscules were at low level in July (6.2\%), August (4.0\%) and September (2.2\%) in roots of A. tripolium. Mycorrhiza in roots of T. fragiferum showed an increasing trend from July to September (Fig. 16D), and arbuscules were found only in August (9.3\%, data not shown). 

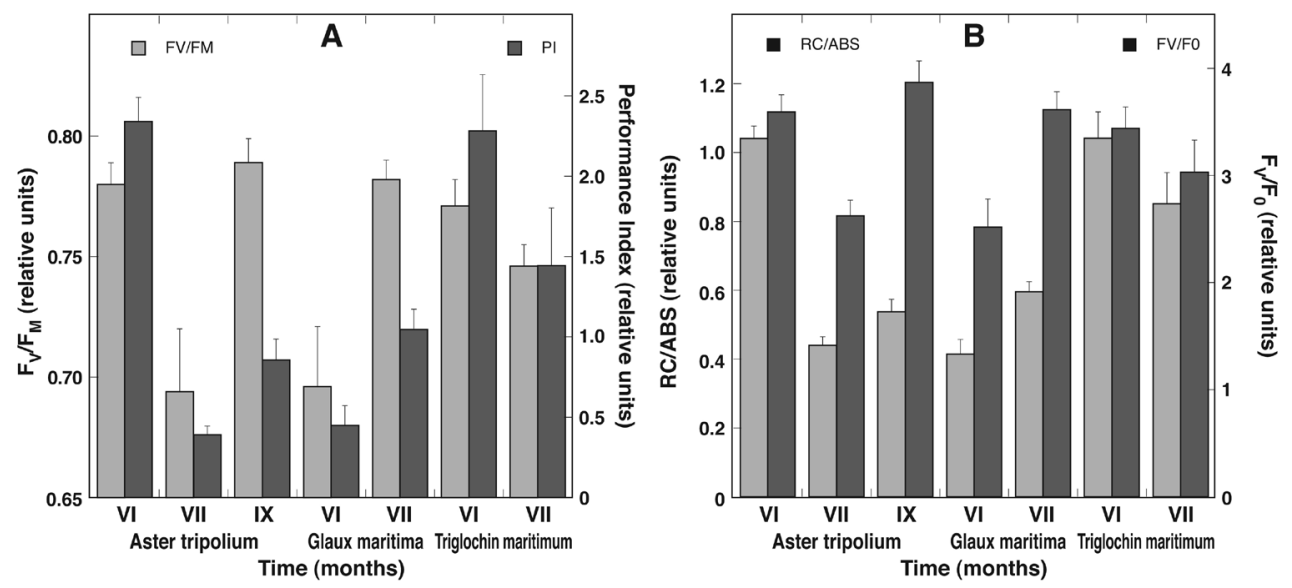

Fig. 17. Seasonal changes of chlorophyll a fluorescence parameters in leaves of Aster tripolium, Glaux maritima, and Triglochin maritima. Data are means \pm SE from 5 measurements from 10 plants for each bar.

Photochemical activity of photosystem II as indicated by chlorophyll $a$ fluoresceence parameters showed significant changes during the season for A. tripolium and G. maritima plants (Fig. 17). Decrease of $F_{v} / F_{m}$ and PI in leaves of A. tripolium plants in July coincided with the lowest level of mycorrhization intensity in roots. In contrast, G. maritima plants had low intensity of chlorophyll $a$ fluorescence parameters in June followed by a significant increase in July. In contrast, no significant changes in photosystem II activity were evident for T. maritima plants, with a tendency to decrease slightly in July.

As it was found that many soil mineral mutrients had similar concentration trends during the vegetation season, relationship between concentrations of different plantavailable mineral nutrients in soil was analyzed (Fig. 18). The most significant correlation $\left(R^{2} 0.90\right.$ to 1.00$)$ was found between $\mathrm{Na}$ and $\mathrm{Cl}$ ion concentration, and both were closely related to soil EC. Soil $\mathrm{N}$ concentration had highly significant correlation with $\mathrm{Cu}, \mathrm{Zn}, \mathrm{Fe}, \mathrm{K}$, and $\mathrm{S}$ concentration ( $R^{2} \quad 0.80$ to 0.89 ), and less pronounced with that of $\mathrm{Na}$ and $\mathrm{B}\left(R^{2} 0.70\right.$ to 0.79$)$. K concentration correlated with that of S, Ca with $\mathrm{Mg}$, Zn with $\mathrm{Fe}, \mathrm{Zn}$ with $\mathrm{Cu}$ and $\mathrm{B}$ (all 0.80 to 0.89 ),

Negative relationship was found between soil $\mathrm{pH}$ and soil EC $\left(R^{2}=-0.678\right)$ and the majority of soil minerals (except $\mathrm{P}, \mathrm{Ca}, \mathrm{Mg}, \mathrm{Mn}$ and $\mathrm{B}$ ) with $R^{2}$ ranging from -0.481 to -0.748 . In addition, soil $\mathrm{Mg}$ was negatively correlated with soil $\mathrm{Cu}, \mathrm{Cl}, \mathrm{Na}, \mathrm{S}, \mathrm{N}$ and $\mathrm{K}$ concentration (with $R^{2}$ values from -0.306 to -0.489$)$, and soil $\mathrm{Ca}$ was negatively correlated with soil $\mathrm{Na}\left(R^{2}=-0.403\right)$ and $\mathrm{Cl}\left(R^{2}=-0.392\right)$. At the level of plant mineral constituents, the most pronounced were correlation between $\mathrm{Na}$ and $\mathrm{Cl}$, and $\mathrm{Cu}$
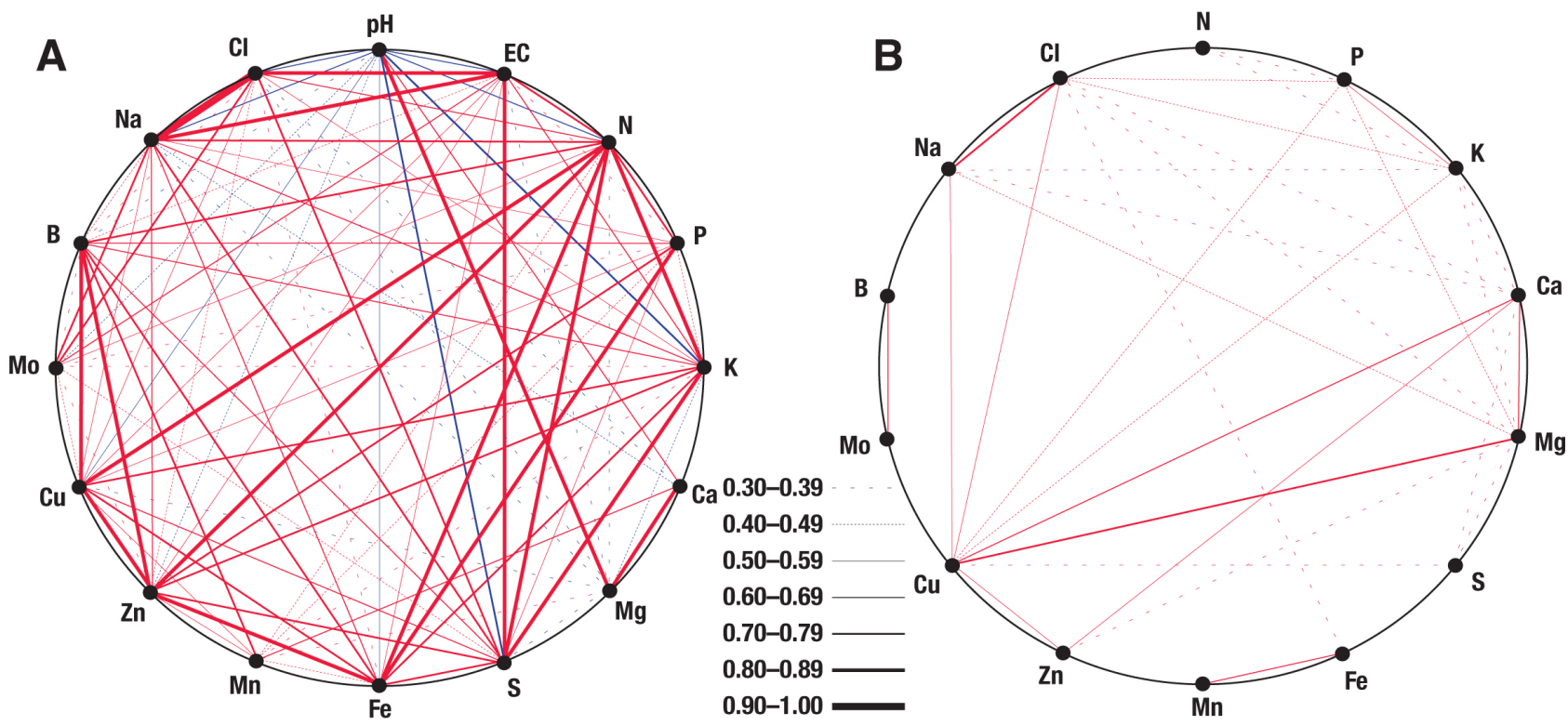

Fig. 18. The correlation between soil (A) and plant leaf (B) mineral constituent concentrations. Only positive (red) and negative (blue) interactions with $R^{2}>0.30$ are shown. 
and $\mathrm{Mg}\left(R^{2} 0.70\right.$ to 0.79$)$. The only negative correlation above 0.300 was that between tissue $\mathrm{Fe}$ and $\mathrm{Cl}$ content $\left(R^{2}\right.$ $=-0.321)$. Other most important negative correlations ranging from -0.203 to -0.266 were between $\mathrm{S}$ and $\mathrm{N}, \mathrm{K}$, $\mathrm{Mo}, \mathrm{B}$; between $\mathrm{Na}$ and $\mathrm{Fe}, \mathrm{Mn}$; between $\mathrm{Mn}$ and $\mathrm{N}$; and between $\mathrm{Cu}$ and $\mathrm{B}$.

\section{Discussion}

In the present study, both spatial and temporal heterogeneity in mineral nutrient concentrations resulted in relatively high variability of particular nutrients in soil samples. While there was extremely high soil chemical heterogeneity within a vegetation season in wetland on a coast of a lagoon lake (Table 1), pronounced correlation between the concentrations of different soil mineral nutrients was observed (Fig. 18A). The study site was far from the sea and the impact of sea water on the wetland soil composition was mediated by the lake water, which came into contact with the sea only through the city channel. Consequently, the correlation between nutrients found is mostly related to mineralization of organic matter during the vegetation season, when the concentration of minerals in soil increase due to decomposition. This relationship was indicated by correlation between the most nutrients, especially between $\mathrm{N}$ and all micronutrients with the exception of $\mathrm{Mn}$ and Mo. Mineralization was also reflected by increasing concentration of $\mathrm{N}$ in the study site. Negative correlation between soil $\mathrm{pH}$ and the majority of nutrients was more likely due to the phenomenon that the highest $\mathrm{pH}$ was detected in the beginning of the vegetation season, when the nutrient availability is lowest. By contrast, in the second half of summer due to effect of rain, soil $\mathrm{pH}$ decreased, but mineralization in the soil and mineral concentrations increased.

At the level of mineral nutrient concentration in plant leaves, the correlation between particular elements was relatively low (Fig. 18B) indicating selective accumulation of different ions in photosynthetic tissues. Most pronounced correlation (in a range of $R^{2}$ between 0.70 and 0.79) was that between $\mathrm{Cu}$ and $\mathrm{Mg}$ concentration, as well as between $\mathrm{Na}$ and $\mathrm{Cl}$.

Halophytes have an ability for selective ion uptake from saline soils (including short- and long-distance transport), as well as possess mechanisms of exclusion, detoxification, and storage (Albert 1975; Breckle 2002). "Salt regulation" often refers to the type of salinity tolerance associated with decrease of interanl concentration of salt either by exclusion (at the root level, by salt glands etc.) or by increase in succulence (Rozema, Gude 1981). In contrast, "salt accumulation" is suggested when there is a continuous increase of interanl salt concentration with increasing external salinity or with time (Albert 1975). However, particular halophyte species can simultaneously use both basic mechanisms of salinity tolerance.
Rosette-forming salt marsh plants A. tripolium, $P$. maritima and T. maritima are characterized as species with limited importance of succulence in salt tolerance, suggesting programmed senescence and removal of old leaves and continuous formation of new ones as the main strategy of salt avoidance (Albert 1975). G. maritima is a species with an ability to replicate vegetatively, characterized by the presence of salt glands on the surface of the shoot as an effective way of removal of salts from the tissues, as well as intracellular osmotic adaptation (Rozema, 1975). T. fragiferum, in turn, is a typical legume characterized by rhizobial symbiosis, which makes it possible to use air nitrogen, and it is facultative halophyte (Nienartowicz, Wilkon-Michalska 1993), with unknown salt-tolerance mechanisms. It can be expected that the studied species have different adaptive mechanisms to dramatically changing salinity and conditions of mineral heterogeneity.

Model plants in the present study can be divided in two groups in respect to accumulation of $\mathrm{Na}$ ions (P. maritima and T. maritima in the first group, and A. tripolium, G. maritima and T. fragiferum in the second), with only slight differences between them in relation to ion accumulation at the end of the vegetation season. The first group of plants had higher tissue concentrations of $\mathrm{Na}$ in August and September. Differences in $\mathrm{Cl}$ dynamics was higher for G. maritima, which accumulated lower levels of $\mathrm{Cl}$ in the first half of the season, but later the differences between the groups diminished. Thus, in heterogeneous environment halophytes of different systematic groups accumulated similar concentrations of salts, in spite of the dramatically different potential mechanisms of salt resistance.

Changes in mineral constituent concentrations in plant tissues are often analyzed only from the point of view of optimality of the particular nutrients, without further analysis of possible functional consequences. Thus, foliar nutrient analysis has been use to predict mineral requirements of crop species (Osvalde 2011). On the other hand, when wild plants grow in native soils, they certainly possess mechanisms of adaptation to particular mineral nutrient composition and concentrations. However, it is obvious that particular changes as a result of changing environmental conditions should reflect dynamics of certain physiologically important chemical substances that contain the elements of interest, as well as reflect dynamics of equilibrium between the acquisition, active use and storage of them. Significantly large differences were found for tissue contents of mineral nutrients in the various wetland model species.

If some important biochemical mechanism is using the particular ion, it's concentration in particular tissues can increase well above toxic threshold level. Also, detoxification of ions by means of compartmentation and complex formation is a strategy against toxicity of high tissue concentrations of particular ions. In the present study, tissue concentrations of several ions were well above 
toxicity levels reported for the majority of crop plants; for example, $\mathrm{Fe}$ (above $100 \mathrm{mg} \mathrm{kg}^{-1}$ ) for all species, Mn (above $300 \mathrm{mg} \mathrm{kg}^{-1}$ ) for G. maritima. It has been shown that moderate to high soil salinity induces $\mathrm{Mn}$ accumulation in leaf tissues of A. tripolium (Karlsons et al. 2008). Therefore, accumulation of Fe and $\mathrm{Mn}$ in leaf tissues of G. maritima can be regarded as an effect provoked by a high soil salinity. Similarly, accumulation of $\mathrm{K}$ ions in leaf tissues of $A$. tripolium can be associated with increased soil salinity, as in controlled conditions high soil salinity resulted in significant increase in tissue $\mathrm{K}$ concentration (Karlsons et al. 2008).

Similar increase of $\mathrm{Cu}$ and $\mathrm{Zn}$ content seen in June in leaves of $A$. tripolium and P. maritima (Fig. 12, 13) coinciding with the highest soil salinity (Fig. 1) points to the involvement of both ions in some resistance mechanism against high salinity. A particular type of superoxide scavenging enzyme, superoxide dismutase, contains both $\mathrm{Cu}$ and $\mathrm{Zn}$ in the active centre of the molecule and is involved in antioxidative defense (Mittler et al. 2004). It is possible, that the increase of leaf $\mathrm{Cu}$ and $\mathrm{Zn}$ concentration revealed in A. tripolium and P. maritima during an episode of high soil salinity is associated with a corresponding increase in $\mathrm{Cu}-\mathrm{Zn}$ superoxide dismutase protein level and activity as a part of resistance to salinity-induced endogenous oxidative stress. It is widely accepted that salinity increases production of reactive oxygen species and that induction of a sufficient level of enzymatic antioxidative capacity is one of the internal factors of salinity tolerance in both glycophytes and halophytes (Miller et al. 2010). Indeed, superoxide dismutase activity increased in A. tripolium plants grown under $75 \%$ seawater salinity (Geissler et al. 2009). In addition, $\mathrm{Cu}$ accumulation is enhanced in $A$. tripolium at increased soil salinity in controlled conditions (Karlsons et al. 2008).

Exclusion of the excess amount of ions from photosynthetic tissues with accumulation in roots is a typical adaptive mechanism of plants allowing not to reach toxic level (Karlsons et al.2011). This is especially important for transitional metals, accumulation of which can lead to formation of hydroxyl radicals in photosynthetic tissues (Mittler et al. 2004). Thus, T. maritima plants grown in a substrate resembling natural soil accumulated 5-fold level of Fe, 10-fold level of Mn, 2-fold level of $\mathrm{Zn}$ and 2-fold level of $\mathrm{Cu}$ in roots in comparison to that in leaves (Karlsons et al. 2011). In the present study, however, G. maritima plants accumulated relatively high tissue concentration in leaves of both Fe and $\mathrm{Mn}$, reaching 1500 and $600 \mathrm{mg} \mathrm{kg}^{-1}$, respectively, in August (Fig. 10B, 11B). This concentration is far above critical toxic levels of $\mathrm{Fe}\left(100 \mathrm{mg} \mathrm{kg}^{-1}\right)$ and $\mathrm{Mn}\left(300 \mathrm{mg} \mathrm{kg}^{-1}\right.$ ) in plant tissues reported (Macnicol, Beckett 1985). However, no physiological signs of toxicity were noticed. In addition, P. maritima was accumulating high concentration of $\mathrm{Ca}, \mathrm{Mg}$ and $\mathrm{S}$ in leaves, especially, at the beginning of the season $(\mathrm{Ca}, \mathrm{Mg})$ or even later (S). Concentration of S in leaves was four-fold the mean concentration of $\mathrm{S}$ usually found in cultivated plants (Osvalde 2011). In controlled conditions, moderate to high soil salinity induced up to two-fold $\mathrm{Mn}$ accumulation un A. tripolium tissues (Karlsons et al. 2008). In contrast, $S$ accumulation in both leaf and root tissues of A. tripolium were significantly inhibited by high salinity (Karlsons et al. 2008). It seems that accumulation of extremely high concetration of particular ions in photosynthetic tissues is a typical physiological characteristic of plants native to chemically heterogeneous soils as in sea-affected wetlands. Possible adaptive significance of the phenomenon needs to be proven experimentally, but chemical sequestration of particular ions in leaf cell vacuoles can be suggested as a possible mechanism of tolerance, as already shown for heavy metals (Sharma et al. 2016).

The problem of mycorrhizal vs. non-mycorrhizal plants is especially important for plants in highly heterogeneous environments. While one of the model species used in the present study, T. maritima, is considered to be only occasionally mycorrhizal (Harley, Harley 1987) or even non-mycorrhizal (Hildebrandt et al. 2001), it did show significant change of mycorrhizal pattern in roots during the vegetation season. The intensity of colonization was not high, but the presence of arbuscules indicated significant functional activity of the symbiosis. In a previous study it was noted that roots of T. maritima contained linear hyphae, vesicles with storage lipid inclusions, as well as arbuscules (Druva-Lūsìte, Ievinsh 2010). In conditions of significantly decreased soil salinity in July, intensity of mycorrhizal symbiosis increased up to $17 \%$, while frequency reached $70 \%$ (Fig. 16E). It has been argued that low intensity of mycorrhizal symbiosis does not suggest its ineffectiveness (Füzy et al. 2008).

Changes in intensity of mycorrhizal symbiosis during the vegetation season have been associated with differences in growth and devlopment of particular species, rather than with changes in abiotic factors (Bohrer et al. 2004). Direct effect of changes in abiotic conditions (temperature, soil moisture) on mycorrhizal symbiosis can not be excluded (Hildebrandt et al. 2001; Tibbett, Cairney 2007). In the present study, seasonal trends in mycorrhizal intensity in roots indeed followed a species-specific pattern, but some similarities were noticed. Firstly, no direct relationship between soil $\mathrm{P}$ concentration and intensity in mycorhizal symbiosis was found. It is usually assumed that $\mathrm{P}$ availability is directly negatively related to mycorrhizal symbiosis, as investment of reduced carbon substances for mycorrhizal growth can be beneficial only in the case of low nutrient availability (Jones et al. 1991). Similarly, fungal colonization parameters did not correlate with soil $\mathrm{P}$ in a study with low-alpine herb species (Ruotsalainen et al. 2002). A more reliable indicator of $P$ translocation through mycorrhizal structures to plant could be the presence of arbuscules, but their intensity increased during the season for P. maritima and T. maritima plants showing no relationship with soil $\mathrm{P}$ concentration. Secondly, increased 
soil salinity seemed to be related to low level of mycorrhizal colonization, at least, for some species. A. tripolium, G. maritima and $T$. fragiferum had a low level of mycorrhizal intensity in July, following increased soil salinity in June. In conditions of moderately high soil salinity (EC 10 to 15 $\mathrm{dS} \mathrm{m}^{-1}$ ) G. maritima plants had constantly very low level of mycorrhization, less than 4\% (Druva-Lūsīte et al. 2008), but in the present study mycorrhization intensity increased up to $52 \%$ in August when soil salinity decreased to $4 \mathrm{dS}$ $\mathrm{m}^{-1}$. Decrease in mycorrhizal intensity can be related to the fact that the respective mycorrhizal fungi may have lower salinity tolerance than their halophytic host plant (JohnsonGreen et al. 2001). It seems that mycorrhizal symbiosis in plants from coastal wetlands serves only a minor role in mineral nutrient acquisition. In addition to improvement of general stress tolerance of mycorrhizal plants (Garg et al. 1006) more specific function of mycorrhizal symbiosis can be related to accumulation of excess levels of metal ions, especially, heavy metals (Leyval et al. 1997; Hildebrandt et al. 2007).

The present study was not aimed at complete characterization of changes in photochemistry of photosynthesis of different salt marsh species due to soil temporal heterogeneity. However, the data presented here clearly show that edaphic conditions related to soil inundation with saline water had significant effect on photochemistry of photosystem II of typical coastal wetland species A. tripolium and G. maritima. Decreased $\mathrm{F}_{\mathrm{v}} / \mathrm{F}_{\mathrm{m}}$ and PI in leaves of $A$. tripolium in July coincided with the lowest intensity of mycorrhizal colonization, possibly related to increased soil salinity in Jume. In contrast, G. maritima had the lowest fluorescence parameters in June, followed by significant increaese in July, when mycorrhizal intensity was lowest. In another study, photosynthetic performance of G. maritima in natural conditions was significantly inhibited due to direct damage to photosystem II only when soil salinity increased above $10 \mathrm{dS} \mathrm{m}^{-1}$ (Druva-Lūsīte et al. 2008).

In conclusion, the results of this study support the hypothesis that wild plants that are native to habitats with drastically heterogeneous soil conditions have developed effective adaptations as a result of evolution, allowing to grow normally and reproduce within a wide range of mineral concentration conditions, as well as under drastic changes in soil salinity.

\section{Acknowledgements}

The presnet study was supported by the grant from the University of Latvia and partially by the National Research Porgramme EVIDEnT.

\section{References}

Albert R. 1975. Salt regulation in halophytes. Oecologia 21: 57-71. Andersone U., Druva-Lūsīte I., Ieviņa B., Karlsons A., N̦ečajeva
J., Samsone I., Ievinsh G. 2011. The use of nondestructive methods to assess a physological status and conservation perspective of Eryngium maritimum L. J. Coastal Conserv. 15: 509-522.

Bohrer K.E., Friese C.F., Amon J.P. 2004. Seasonal dynamics of arbuscular mycorrhizal fungi in differing wetland habitats. Mycorrhiza 14: 329-337.

Breckle S.-W. 2002. Salinity, halophytes and salt affected natural ecosystems. In:Lauchli A.,Luttge U.(eds) Salinity: Environment - Plants - Molecules. Kluwer Academic Publishers, Dordrecht, pp. 53-77.

Cabinet of Ministers of Latvia. 2000. Regulations About the List of Especially Protected and Restrictedly Used Especially Protected Species of Latvia. MK Regulations No. 396, 14.11.2000. Latvijas Vēstnesis No. 413/417. /in Latvian/

Druva-Lusite I., Ievinsh G. 2010. Diversity of arbuscular mycorrhizal symbiosis in plants from coastal habitats. Environ. Exp. Biol. 8: 17-34.

Druva-Lūsīte I., Karlsons A., Osvalde A., N̦ečajeva J., Ievinsh G. 2008. Photosynthetic performance and mycorrhizal symbiosis of a coastal marsh plant, Glaux maritima, in conditions of fluctuating soil salinity. Acta Univ. Latv. 745: 155-164.

Feng G., Zhang F.S., Li X.L., Tian C.Y., Tang C., Rengel Z. 2002. Improved tolerance of maize plants to salt stress by arbuscular mycorrhiza is related to higher accumulation of soluble sugars in roots. Mycorrhiza 12: 185-190.

Füzy A., Biró B., Tóth T., Hildebrandt U., Bothe H. 2008. Drought, but not salinity, determines the apparent effectiveness of halophytes colonized by arbuscular mycorrhizal fungi. J. Plant Physiol. 165: 1181-1192.

Garg N., Kaur G.A. 2006. Arbuscular mycorrhiza: Nutritional aspects. Arch. Agron. Soil Sci. 52: 593-606.

Geissler N., Hussin S., Koyro H.-W. 2009. Elevated atmospheric $\mathrm{CO}_{2}$ concentration ameliorates effects of $\mathrm{NaCl}$ salinity on photosynthesis and leaf structure of Aster tripolium L. J. Exp. Bot. 60: 137-151.

Grattan S.R., Grieve C.M. 1999. Salinity-mineral nutrient relations in horticultural crops. Sci. Hortic. 78: 127-157.

Harley J.L., Harley E.L. 1987. A check-list of mycorrhiza in the British flora. New Phytol. 106: 1-102.

Hildebrandt U., Janetta K., Ouziad F., Renne B., Nawrath K., Bothe H. 2001. Arbuscular mycorrhizal colonization of halophytes in Central European salt marshes. Mycorrhiza 10: 175-183.

Hildebrandt U., Regvar M., Bothe H. 2007. Arbuscular mycorrhiza and heavy metal tolerance. Phytochemistry 68: 139-146.

Johnson-Green P., Kenkel N.C., Booth T. 2001. Soil salinity and arbuscular mycorrhizal colonization of Puccinellia nuttalliana. Mycol. Res. 105: 1094-1110.

Jones M.J., Durall D.M., Tinker P.B. 1991. Fluxes of carbon and phosphorus between symbionts in willow ectomycorrhizas and their changes with time. New Phytol. 119: 99-106.

Karlsons A., Osvalde A., Ievinsh G. 2011. Growth and mineral nutrition of two Triglochin species from saline wetlands: adaptation strategies to conditions of heterogeneous mineral supply. Environ. Exp. Biol. 9: 83-90.

Karlsons A., Osvalde A., N̦ečajeva J., Ievinsh G. 2008. Changes of nutritional status of coastal plants Hydrocotyle vulgaris and Aster tripolium at elevated soil salinity. Acta Univ. Latv. 745: 165-177.

Latvian Environmental Protection Fund. 2008. Nature Protection Plan of the Protected Area "Lake Liepajas". Carl Bro, Riga. 140 p. 
Leyval C., Turnau K., Haselwandter K. 1997. Effect of heavy metal pollution on mycorrhizal colonization and function: physiological, ecological and applied aspects. Mycorrhiza 7: 139-153.

Macnicol R.D., Beckett P.H.T. 1985. Critical tissue concentrations of potentially toxic elements. Plant Soil 85: 107-129.

Miller G., Suzuki N., Ciftci-Yilmaz S., Mittler R. 2010. Reactive oxygen species homeostasis and signalling during drought and salinity stress. Plant Cell Environ. 33: 453-467.

Mittler R., Vanderauwera S., Gollery M., Van Breusegem F. 2004. Reactive oxygen gene network of plants. Trends Plant Sci. 9: 490-498.

Nienartowicz A., Wilkon-Michalska J. 1993. The application of numerical analysis to comparison of ecological amplitudes of halophytic species. Variab. Evol. 2/3: 103-112.

Osvalde A. 2011. Optimization of plant mineral nutrition revisited: the roles of plant requirements, nutrient interactions, and soil properties in fertilization management. Environ. Exp. Biol. 9: $1-8$.

Rozema J., Buizer D.A.G., Fabritius H.E. 1978. Population dynamics of Glaux maritima and ecophysiological adaptations to salinity and inundation. Oikos 30: 539-548.

Rozema J., Gude G. 1981. An ecophysiological study of the salt secretion of four halophytes. New Phytol. 89: 201-217.

Ruiz-Lozano J.M., Azcón R. 2000. Symbiotic efficiency and infectivity of an autochthonous arbuscular mycorrhizal Glomus sp. from saline soils and Glomus deserticola under salinity. Mycorrhiza 10: 137-143.

Rumbaugh M.D., Pendery B.M., James D.W. 1993. Variation in the salinity tolerance of strawberry clover (Trifolium fragiferum L.). Plant Soil 153: 265-271.

Ruotsalainen A.L., Väre H., Vestberg M. 2002. Seasonality of root fungal colonization in low-alpine herbs. Mycorrhiza 12:29-36.

Sharma S.S., Dietz K.-J., Mimura T. 2016. Vacuolar compartmentalization as indispensable component of heavy metal detoxification in plants. Plant Cell Environ. 39: 11121126.

Tibbett M., Cairney J.W.G. 2007. The coller side of mycorrhizas: their occurence and functioning at low temperatures. Can. J. Bot. 85: 51-62. 